\title{
O JOGO INTERATIVVO NA CONSTRUÇÃO FÍLMICA: JEAN ROUCH EM TRÊS TEMPOS $^{1}$ \\ Daniela Dumaresq ${ }^{2}$
}

\begin{abstract}
Resumo: Este artigo analisa as formas de interação entre o eu e o outro em três filmes do diretor francês Jean Rouch: Eu, um negro (1957), Crônica de um verão (1960) e Os tambores do passado (1971). Rouch foi um mestre na arte de criar filmes baseando-se no método da improvisação e da criação de personagens e narrativas a partir do encontro entre o aparato cinematográfico $e$ os atores. Em seus filmes, a câmera funciona como elemento catalisador de relações sociais que estão na origem da narrativa que vemos na tela. Nesses filmes, a relação entre observador e observado é lastreada por um acordo. Os atores são informados sobre a presença de câmeras e microfones e concordam, em alguma medida, em servir de base para a construção das personagens fílmicas. A relação de alteridade aqui pressuposta se dá, então, entre um eu-aparato cinematográfico e um outroestrangeiro a esse aparato, mas que a ele se oferece.
\end{abstract}

Palavras-chave: Interação. Documentário. Análise Fílmica.

\begin{abstract}
This article is an analysis of forms of interaction between the I and the other in three Jean Rouch's films I, a Black (1957), Chronicle of a Summer (1960) and The Drums of Yore: Turu and Bitti (1971). Rouch was a master in the art of creating films based on improvisation and on the creation of characters and narratives from the meeting between the cinematographic apparatus and the actors. In Rouch's films the camera works as a promoter of social relationships that are in the narrative origin that we see on the screen. In those films the relationship between the observer and the observed is reinforced by an agreement: the actors are informed about the presence of cameras and microphones and they agree, in some way, to be the base for the construction of the film characters. The relationship of alterity presupposed here is between on I-cinematographic apparatus and other-stranger to that apparatus, even though he/she offers $\mathrm{him} / \mathrm{herself}$ to it. Itself
\end{abstract}

Key words: Interaction. Documentary. Film Analysis.

\section{Introdução}

O cineasta e antropólogo francês Jean Rouch foi um mestre na arte de criar filmes baseando-se no jogo interativo entre o eu-aparato cinematográfico e o outro-estrangeiro a esse aparato, mas que a ele se oferece. A reflexão sobre tal jogo interativo tem por base o trabalho de Erwin Goffman (1996) no qual o autor trata do jogo entre o observador e o observado. Essa relação pressupõe não apenas as pessoas envolvidas, mas o aparato que as acompanha e

\footnotetext{
${ }^{1}$ Este artigo foi originalmente apresentado de forma oral no III Encontro de Ciências Sociais do Estado do Ceará.

2 Professora do curso de Cinema e Audiovisual da Universidade Federal do Ceará. Email: danidumar@gmail.com.
} 
o lugar onde ocorre a interação. No caso do cinema, ela não se limita àquela estabelecida entre o diretor ou produtor e os atores. O eu refere-se ao aparato cinematográfico, envolvendo as pessoas, os equipamentos assim como as práticas específicas da produção cinematográfica e nem sempre compartilhadas pelo outro. $\mathrm{O}$ outro seriam as pessoas que se oferecem para serem filmadas (englobando seus aparatos particulares, suas maneiras de ser e de agir). $\mathrm{O}$ lugar é aquele que serve de locação, onde se desenrolam as situações filmadas. Esse lugar pode pertencer a um dos dois pólos envolvidos no jogo, caso contrário é considerado neutro.

Neste artigo, busco refletir sobre as formas de interação entre o eu e o outro em três filmes do diretor francês: Eu, um negro (filmado em 1957), Crônica de um verão (filmado em 1960, em parceria com Edgar Morin) e Os tambores do passado (filmado em 1971). Nos filmes escolhidos para análise, a relação entre observador e observado é fruto de um acordo. Os atores são informados sobre a presença de câmeras e microfones e concordam, em alguma medida, em servir de base para a construção das personagens fílmicas. O diálogo entre o eu e o outro está na base da criação de seus filmes e as situações são fruto de um acordo entre os dois. A situação de filmagem funciona como um catalisador, instigando a revelação de si (do ator) para a câmera.

Os três filmes dialogam com as reflexões que animavam as ciências sociais nos anos cinquenta, quando as formas de relação entre o eu e o outro passaram para o centro das preocupações de antropólogos e sociólogos. O outro deixava de ser percebido apenas como um objeto de estudo, alguém para quem se olha, e começava a ser entendido como um sujeito com quem o pesquisador trava uma relação. Essa preocupação com as formas de interação aparecem nos trabalhos de Erving Goffman e Jean Rouch sobre os quais nos deteremos neste artigo.

Goffman publica em 1959 o seu A representação do eu na vida cotidiana. Em linhas gerais, o livro apresenta a discussão sobre como representamos na tentativa de regular a impressão causada nas pessoas com as quais interagimos, e como assumimos personagens diferentes de acordo com a situação em que nos encontramos. Ao falar de representação, Goffman não se refere a 'enganar'. Para exemplificar, ele nos remete a dois tipos extremos de atores, um 'sincero' e o outro 'cínico': “quando o indivíduo não crê em sua própria atuação e não se interessa em última análise pelo que seu público acredita, podemos chamá-lo de cínico, reservando o termo 'sincero' para os que acreditam na impressão criada por sua representação" (Goffman, 1996: 25-26).

A discussão sobre a possibilidade de uma atuação sincera está no centro mesmo de Crônica de um verão, lançado em 1961. Nesse filme, Rouch e Morin experimentam diferentes 
formas de interação: conversas, entrevistas, debates, encontros provocados, e estimulam a encenação da vida cotidiana. As duas seqüências finais mostram, primeiro uma projeção das filmagens para os atores e a conversa sobre as impressões que eles tiveram dessa experiência; por fim, os diretores conversam entre si. Essa conversa final entre os dois diretores gira em torno da possibilidade de os atores terem sido sinceros nesses encontros provocados e registrados pela câmera. Para os próprios participantes, diante da câmera as pessoas se comportariam como intérpretes, representando alguém diferente de si, ou como exibicionistas. Nessas circunstâncias seria difícil encontrar a verdade de cada um. Para os diretores, diante da câmera seus atores foram um pouco mais sinceros que na vida cotidiana, ao revelarem certas intimidades mantidas inacessíveis em suas relações cotidianas, mas não seriam nem exibicionistas nem intérpretes. Representando a si mesmos diante da câmera, esses atores fogem dos contratos de sociabilidade aos quais estão habituados na vida cotidiana e revelam outra porção de si, talvez mais verdadeira, certamente autêntica.

Esse caráter de experimentação sobre as possibilidades relacionais colocou o filme como o pioneiro de certo estilo cinematográfico. Em Bill Nichols, ele aparece ao lado dos filmes do modo interativo ou participativo, sendo um dos filmes que marcam o modo (Nichols, 1991: 44 e 2005: 155). Para Erik Barnouw, a partir de Eu, um negro, Rouch começa a se perguntar cada vez mais “como poderia instigar momentos de revelação?”, desenhando as características que seriam cristalizadas em Crônica de um verão: precipita crises, ao invés de esperar por elas; participa da situação, ao invés de se fazer invisível; provoca acontecimentos, ao invés de limitar-se a filmá-los (Barnouw, 1993: 254-255). Os tambores do passado mostra como essa provocação pode ser levada ao extremo quando o espaço do outro já não é percebido como diferente do espaço próprio. Nessa situação, observador e observado confundem-se a ponto de romper fronteiras. Filmados em épocas diferentes e lançando mão de diferentes recursos não é possível apontar uma evolução entre os filmes. Cada filme constitui um momento único em que o jogo interativo é experimentado de forma diversa, nem melhor nem pior que as demais. Por enquanto, deter-se em Eu, um negro ajudará a compreender os problemas que esse método baseado na interação e na provocação pode trazer para a equipe cinematográfica.

\section{O ator social em $E u$, um negro}

$E u$, um negro fala de uma África urbana. Essa África aparece distante das paisagens de savanas habitadas por animais selvagens que povoa o imaginário ocidental. Em seu lugar, o filme oferece uma cidade com seus problemas de desemprego e seus processos migratórios. $\mathrm{O}$ 
filme mostra um grupo de imigrantes que deixaram a savana para tentar a sorte em Abidjan, capital da Costa do Marfim. Na cidade, esses imigrantes se distraem à maneira dos ocidentais, assistem a filmes americanos no cinema e sonham ser Marlon Brandon. Ou melhor, sonham ser Edward G. Robinson, Eddie Constantine e Dorothy Lamour ${ }^{3}$. Rouch e sua câmera posicionam-se no centro da contaminação cultural que faz conviver a cultura do colonizador francês, o estilo de vida americano disseminado pelos filmes e as tradições africanas das savanas e das cidades. Como personagem de filme, o ator social pode ser estrela de cinema ou pelo menos adotar os nomes das estrelas que admiram e acreditarem-se rapazes conquistadores como Constantine e garotas belas como Lamour. O filme de Rouch permite que seus atores realizem diante da câmera seus sonhos e desejos. E aqui se encontra a base do jogo interativo de $E u$, um Negro. O filme abre mão de observar à distância a vida dos imigrantes e se interessa pelo imaginário, pelo impalpável, pelo intangível. As conversas fora das filmagens garantem o acesso a esse universo de sonhos e desejos. Dessa forma, Rouch elabora uma dramaturgia ancorada nas histórias de vida e histórias de sonhos, fazendo com que esses universos se confundam no filme. No cinema, esses universos podem conviver em harmonia, ainda que se saiba que há um dia seguinte, um dia em que a câmera será desligada ou que as luzes do teatro se acenderão.

Ao dialogar com os atores para decidir sobre a história contada e ao fazer da personagem Robinson também um narrador (que chamaremos narrador auxiliar), o filme instaura certa tensão na relação entre observador e observado. A experiência conduzida por Rouch revela um tipo de problema: a possibilidade de o ator social não compreender bem o seu papel, uma vez posto nesse lugar de encontro entre o aparato cinematográfico e seu lugar próprio. Para o ator, a representação de si diante da câmera traz a dificuldade de adaptar-se a um novo papel social.

\footnotetext{
${ }^{3} \mathrm{O}$ ator Edward G. Robinson, de origem Romena, despontou em Hollywood com o filme Little Caesar (Sem título no Brasil, Mervyn Le Roy, 1931), no papel de um homem “justo, brutal e estúpido sem que nenhum traço adoçasse a personagem". Foi um dos responsáveis pela criação do "mito ambíguo do gangster, acolhido por uma América em crise". Mas suas criações dos anos 50 e 60 "são composições plenas de calor humano". Por fim, "Robinson não é um mito, mas um ator de composição, um dos maiores, e empregou sua arte em uma série de papéis bem diversos". Robinson atuou em A cidade sem Lei (Barbary Coast, Howard Hawks, 1935); O Estranho (The Stranger, Orson Welles, 1946); Paixões em Fúria (Key Largo, John Huston, 1948); Os Dez Mandamentos (The Ten Commandments, Cecil B. de Mille, 1956); Os Viúvos também sonham (A hole in the head, Frank Capra, 1959). Eddie Constantine, descendente de russos, estreou cantando em operetas e tornou-se popular no cinema nos anos $50 \mathrm{com}$ a personagem Lemmy Caution. Constantine atuou em Les Femmes s'en balancent (sem título no Brasil, Bernard Borderie, 1953); Alphaville (Alphaville: une étrange aventure de Lemmy Caution, JeanLuc Godard, 1965); Europa (Europa, Lars Von Trier, 1991). Dorothy Lamour começou a carreira como Miss Nova Orleans em 1931 e ficou conhecida por sua beleza morena. Atuou em O Furacão (The Hurricane, John Ford, 1938) e O maior espetáculo da Terra (The Greatest show on Earth, Cecil B. DeMille, 1952). Ver verbetes referentes aos atores em Passek, 1991.
} 
Pensar no cineasta como provocador e no filme como fruto de um processo interativo - caminhos apontados por Nichols e Barnouw -, leva-nos de volta a Goffman, e a busca de procurarmos compreender as modificações provocadas na vida cotidiana e no processo interativo quando a câmera entra em cena. Segundo Goffman, quando na presença de outros, o indivíduo representa na intenção de transmitir certa impressão a respeito de si, a impressão que o interessa provocar (Goffman, 1996: 13). Isso não implica necessariamente um desvio moral. Não se trata de enganar deliberadamente os interlocutores ou observadores, mas de informar a respeito de si e da maneira como se espera ser tratado. De modo geral, cada um espera ser tratado de maneira adequada às características que demonstra ter e, em uma representação sincera, deve possuir. Assim, quando alguém projeta de si certa imagem, seu interlocutor espera que de fato esse alguém corresponda à imagem projetada. Para o autor, essa inferência está na base da relação entre os indivíduos. Resulta disso uma expectativa positiva e outra negativa: espera-se ser tratado de acordo com as características projetadas e abre-se mão do tratamento dispensando às pessoas que projetam de si características distintas. Ou seja, a imagem que projetamos de nós mesmos informa não apenas quem somos, mas, também, o que esperamos que os outros entendam a nosso respeito;consequentemente, orienta a forma de tratamento que os outros nos dispensam (Goffman, 1996: 21). Assim, ao se oferecer para a câmera, o indivíduo escolhe a porção de si que deseja oferecer ao aparato cinematográfico e ao público.

Esse indivíduo filmado está na base da construção de uma personagem fílmica e tenta manter o controle da imagem de si que será ofertada, em última instância, ao público. Mas o resultado nem sempre é o por ele esperado. O ator Oumarou Ganda não se reconheceu na imagem de si projetada em $E u$, um negro. De uma maneira geral diz, em entrevista concedida a Pierre Hafner, que Rouch não o pressionou a fazer ou dizer qualquer coisa, mas parece não ter gostado nem do resultado do filme nem da experiência:

...pessoalmente não gostei muito desse filme. Por várias razões. Primeiro, em certo momento ele me soa falso. Depois, eu senti que a realização do que eu pensava deveria ser diferente, porque, na realidade, eu fui também corealizador deste filme, eu contribuí no dia-a-dia, nós trabalhamos juntos, e depois Rouch fez a montagem (Ganda em entrevista a Hafner, 1996: 97).

Sua personagem, Robinson, é a figura central do filme. Através de Robinson, o filme de Rouch conta a história dos imigrantes africanos que deixam as savanas para buscarem melhores oportunidades nas zonas urbanas. Como observou Ganda, o filme foi produzido em colaboração e os atores tiveram liberdade para escolherem as porções de si e de seus 
imaginários que desejavam mostrar. No set de filmagem, essa atitude aparece como o deslocamento do papel clássico do outro-observado. O outro é sujeito de sua história e colabora ativamente para a forma como ela será narrada no filme. Na narrativa fílmica ele assume o papel de narrador auxiliar: Robinson colabora para a construção da narrativa emitindo opiniões e falando de si, de seus colegas, da vida em Treichville, o bairro onde vivem os imigrantes. O narrador auxiliar divide com o narrador, dentro do filme, a responsabilidade de organizar e contar a história. Dessa forma, o outro já não sofre "passivamente" a observação, mas é tomado como alguém de opinião e vontade, alguém que age. Enfim, ele é também sujeito. Robinson/Ganda é ao mesmo tempo personagem e sujeito da narrativa assim como do processo de construção do filme. Mas em nenhum lugar encontramos Ganda como correalizador. Nisso os créditos são claros: "Um filme de Jean Rouch". Ganda ofereceu sua 'representação de si' para ser filmada e não gostou do que fizeram com ela. Ao interpretar Robinson para a câmera de Rouch, ele tinha uma autoimagem a constituir e preservar. Para o cineasta, o ator é um instrumento que lhe ajuda a contar uma história. Assim, Ganda/Robinson e Rouch têm posições e objetivos diferentes. Rouch leva certamente vantagem por ocupar o lugar do observador, tendo seu poder ampliado pelo controle do processo produtivo.

A entrevista de Ganda permite pensar em duas hipóteses: a) ele confundia seu lugar no jogo entre "ator" e "realizador" e b) ele se sabia ator e confundia quais seriam as atribuições dessa nova função que ele acabava de assumir. As experiências de vida preparam o indivíduo para os espaços de sociabilidade e o guiam quando está diante de um novo papel social. Essas experiências passadas não precisam ser necessariamente semelhantes às novas situações. A dinâmica social mostra que nunca se está inteiramente informado sobre como se comportar diante de uma situação nova. No entanto, em casos como esse, é sempre possível recorrer às experiências passadas - ao repertório particular - em busca de orientação. Como diz Goffman, não haveria tempo ou energia para um indivíduo aprender em todos os detalhes um único papel. Espera-se dele a capacidade de aprender um conjunto de formas de expressão que lhe permita depois dirigir sua própria atuação em um novo papel, inclusive preenchendo as lacunas (Goffman, 1996: 72-73). Goffman fala nessa passagem sobre como deve se comportar - quais maneiras deve assumir - uma pessoa em uma determinada situação. A situação proposta a Ganda foi "representar seu próprio papel diante da câmera e, assim, mostrar como é a vida dos imigrantes em Treichville, bairro pobre de Abidjan". O filme permite concluir que ele cumpriu satisfatoriamente esse papel. No entanto, sua entrevista revela certa confusão: Ganda acreditava ter um papel diferente, o de correalizador. Dessa 
forma não seria exatamente um problema de atuação social, mas de avaliação de seu papel social. Convidado para o papel de ator ele se imaginou como diretor. O que torna particularmente curiosa a declaração de Ganda é tê-la proferido numa época em que ele mesmo já era cineasta, e deveria conhecer minimamente os mecanismos de construção do filme assim como os papéis de cada um neste cenário, ou seja, no set de filmagem.

\section{Experimentos em torno do jogo interativo}

É possível dizer que Rouch, com Eu, um negro, ao propor e aceitar sugestões de seus atores colabora para redimensionar a verticalidade da relação entre o eu-aparato cinematográfico e o outro que se oferece a esse aparato. No entanto, o descontentamento expresso por Ganda alerta para o tipo de confusão possível que a equipe de filmagem terá de enfrentar. Sem conhecer a lógica de funcionamento própria ao lugar do observador, o ator social pode incorrer em erros de avaliação diante desse novo papel a ser representado. Esse é um risco iminente no jogo interativo.

Os outros dois filmes de Rouch apresentam soluções um pouco diferentes para as formas de interação entre o aparato cinematográfico e os atores sociais. Crônica de um verão e Os tambores do passado se apresentam como experimentos. "Esse filme não é interpretado por atores, mas vivido por homens e mulheres que doaram um momento de suas vidas a uma experiência nova: o cinema-verdade", diz a voz-over no início de Crônica de um verão. Também o início de Os tambores do passado aponta para a construção de um conceito cinematográfico com base na experiência do momento da filmagem ${ }^{4}$. No início do filme, a voz-over explica que o aparato cinematográfico estava preparado para filmar um rito de possessão. A equipe aguardava o momento de entrar em cena, mas os espíritos não se manifestavam:

Ao final da tarde, nenhum dançarino havia sido possuído e decidimos, o técnico de som Moussa'Hamidou e eu mesmo com a câmera, realizar, apesar de tudo, um plano-sequência de uma dezena de minutos, a fim de conservar um documento filmado em tempo real sobre esses tambores antigos que logo pararão para sempre. Assim, essa filmagem é o cinema etnográfico em primeira pessoa.

As explicações oferecidas mostram ambos os filmes se propondo a ensaiar formas de relação entre o eu e o outro. O primeiro abertamente declarado como nova experiência,

\footnotetext{
${ }^{4}$ Os conceitos reivindicados no interior do filme, "cinema-verdade" e "cinema etnográfico em primeira pessoa", ganharam uma expressão elaborada a partir do diálogo entre a análise fílmica e a reflexão teórica. Chegou-se assim a dois conceitos constantemente presentes na literatura sobre o cinema rouchiano: câmera-provocação e Cine-transe. Neste trabalho, abandono tais conceitos a fim entender os significados dos conceitos reivindicados pelos filmes.
} 
enquanto o segundo anuncia seu improviso diante de um imprevisto. Mas se a disposição para negociar com o outro é explicitada em Crônica de um verão, ela não é menos profícua em $O s$ tambores do passado. No primeiro, o método da interação se anuncia em diferentes momentos e, assim, também é possível acompanhar os artifícios utilizados para a feitura do filme. Em Os tambores do passado vê-se como a entrada em cena do aparato cinematográfico modifica definitivamente o espaço cênico, revelando o acontecimento que passa a existir para a câmera.

Assim como aconteceu em Eu, um negro, Crônica de um verão e Os tambores do passado experimentam formas de relação que buscam romper com a noção positivista de um eu-observador e um outro-observado na qual cada um manteria seu papel como se fosse possível ignorar a presença um do outro. Levado ao limite, o modelo positivista suporia a não contaminação das atitudes, gestos e ações do observado pela presença do observador e viceversa. Sabemos, no entanto, ser essa uma situação de laboratório. Na vida cotidiana, desde que ambos estejam conscientes da presença um do outro, o jogo entre observador e observado sofre constante influência das ações e reações de ambos os pólos. Ao reconhecer isso, pode-se tentar minimizar a interferência provocada por esse encontro. Neste sentido, pode-se, por exemplo, limitar a participação do observador, ou mesmo "limpar" os efeitos dessa participação, retirando do filme as marcas mais visíveis dos momentos suscitados pela interação. O caminho escolhido por Rouch é justamente o oposto. Como diz Marsolais, todo o cinema de Rouch se situa na afirmação e na exploração de uma assumida "objetividade subjetiva" (Marsolais, 1997: 185), indicando que a objetividade da observação depende da subjetividade dos envolvidos na situação de interação.

O que difere os filmes não é a exploração da objetividade subjetiva, mas as formas que ela assume em cada um deles. A discussão sobre a relação eu-outro dá-se, então, em torno de duas questões principais: 1) como, no interior do filme, o público pode perceber as maneiras de agir do aparato cinematográfico. Ou seja, apenas olhando o filme é possível saber algo da relação estabelecida entre o eu e o outro? Se sim, então quais seriam as marcas tornadas visíveis? e 2) o outro, ao se oferecer para a câmera, acrescenta algo de particular ou é mero objeto de observação? Eu, um negro, Crônica de um verão assim como Os tambores do passado são filmes construídos a partir de uma relação eu-outro cujos pólos agem e interferem nas atuações um do outro. Nos três filmes, a presença do observador é manifesta, embora de formas distintas. No primeiro, a voz de Rouch pontua a narrativa e guia o espectador entre os diferentes momentos. Em Crônica de um verão as regras do jogo interativo são apresentadas ao outro e ao público e muitas negociações acontecem diante da 
câmera, mesmo que não todas. Em Os tambores do passado anuncia-se um contrato que logo será rompido: o convite ao registro transmuta-se em participação essencial ao rito. Quanto à explicitação das negociações, os últimos dois filmes diferem de $E u$, um negro, pois apenas sabemos de como se deu sua construção por informações extrafilme. Embora, no interior do filme, a instauração de um narrador auxiliar seja um poderoso instrumento no processo de tornar o outro sujeito.

\section{Crônica de um verão e a exposição do aparato cinematográfico}

Uma das cenas iniciais de Crônica de um verão mostra os diretores Rouch e Morin explicando o projeto do filme a uma das atrizes. Nesse momento, o filme explicita-se também para o público. O problema da interação entre o eu-aparato cinematográfico e o outro-ator assume imediatamente o primeiro plano. Rouch duvida da possibilidade de uma conversação não ser alterada pela presença da câmera, chamando a atenção para a nova configuração do espaço proporcionada pela presença da equipe de filmagem e seu aparato. A atriz Marceline confessa sentir-se intimidada diante da situação e teme não estar pronta na hora em que for preciso, ou seja, na hora de gravar. Essa preocupação com o "estar pronta" remete a certo paradoxo do ator que representa a si mesmo no cinema. Por um lado há a sua vontade de colaborar com o filme, correspondendo às expectativas dos diretores; por outro a preocupação com a preservação de sua autoimagem. Esses dois interesses não são necessariamente contraditórios. É possível negociar com o ator uma aparição que sirva aos anseios do filme, diga-se à construção da personagem, sem agredir sua autoimagem. Em Crônica de um verão o espectador pode ver essa negociação. Rouch propõe a Marceline uma astúcia para se saírem bem ela e o filme. Ela pode responder às perguntas com a garantia de que, caso algo lhe desagrade, será cortado do filme. Dessa forma, além de tranquilizar sua interlocutora, ele anuncia a busca de uma conciliação entre os interesses do eu e do outro. E Marceline, que anunciava seu temor diante da hora de gravar, já o fazia diante do outro, ou seja, entregandose em confiança ao aparato cinematográfico.

O filme experimenta diferentes formas de interação. Os atores são motivados a dialogarem entre si, a conversarem em grupos dirigidos por Rouch e Morin, a criticarem os resultados das filmagens e, antes do fim, o filme mostrará o diálogo entre os dois diretores. Ao explorar diferentes formas de interação e expor muitas de suas estratégias, Crônica de um verão desdobra os pontos de vista que compõem o filme e expõe os limites da objetividade cinematográfica. Como nos diz François Niney, mesmo parecendo para alguns críticos ser anedótico, girar em torno do próprio umbigo ou soar falso, o filme levanta uma questão 
importante: a das convenções estéticas e sociais sobre os limites entre o subjetivo e o objetivo (Niney, 2002: 162). Assim, uma novidade trazida por Crônica de um verão é a exposição dessa problemática.

O desdobramento do lugar do observador configura momentos em que o filme rompe com as convenções sobre os limites entre subjetivo e objetivo. Podemos perceber essa característica na cena em que duas das protagonistas passam a representar o aparato cinematográfico como entrevistadoras. Marceline e Nadine escolhem, na rua, pessoas para responderem a questões sobre o tema da felicidade. Nessa cena, elas se colocam diante de seus entrevistados como parte do aparato cinematográfico e assumem em relação a eles o papel de observadoras. No entanto, na medida em que são também personagens do filme, elas seguem sendo observadas. Nesse momento, há um desdobramento dos olhares que constroem o filme com as atrizes ocupando uma posição ambígua: para seus entrevistados elas são parte do aparato cinematográfico, para este elas são seu outro. Tal ambiguidade ajuda a revelar a assimetria da relação eu-outro. Tal assimetria não diz respeito apenas a esse filme ou ao cinema documentário, mas ao próprio jogo observador-observado, no qual o observador assume o papel principal, conforme demonstrou Goffman, ao tratar da "assimetria fundamental no processo de comunicação" (Goffman, 1996: 16). No caso do cinema, recai sobre o aparato cinematográfico a primazia do observador. O filme revela tal assimetria ao borrar as fronteiras que separariam o eu e o outro, criando um lugar ambíguo: elas observam os transeuntes de Paris, mas permanecem inexoravelmente observadas pelo aparato cinematográfico. Assim, a novidade em Crônica de um verão não seria a subversão da noção de assimetria fundamental, mas a sua exposição.

A cena inicial do filme, ao mostrar Rouch e Morin negociando com Marceline sua atuação, expõe o jogo entre o eu e o outro um grau além em relação à cena abordada no parágrafo anterior. Naquele momento os diretores são também atores. Como Marceline e Nadine entrevistando os transeuntes de Paris, a posição deles é também desdobrada. Dentro do filme eles também se oferecem à câmera e ocupam um lugar entre o observador e o observado. Além disso, o filme deixa claro para o público que o observador não se resume às pessoas dos diretores, pois um olho exterior a eles continua seu trabalho de observar enquanto eles se metamorfoseiam em personagens. Nessa condição, eles tornam ainda mais manifesta a relação estabelecida entre o eu e o outro, uma vez que assumem no interior do filme o papel do eu-aparato cinematográfico. Em diferentes cenas, o filme mostra como eles orientam e conduzem os atores, motivam e dirigem os diálogos e as conversas, provocando situações ou explorando as possibilidades oferecidas pelos seus atores. É Rouch quem apresenta o operário 
Angelo ao estudante africano Landry. É Morin quem conduz boa parte das entrevistas do filme. Ele ainda introduz nas rodas de conversa o tema das guerras da Argélia e do Congo Belga, enquanto Rouch traz à tona o tema dos campos de concentração ao chamar atenção para o número tatuado no braço da judia Marceline. Nessas cenas, Rouch e Morin atuam para a câmera (para o público) como os diretores costumam atuar nos bastidores, ou seja, longe do ângulo de visão da lente. A novidade não está no que eles dizem ou fazem, pois suas ações são inerentes ao aparato cinematográfico. O raro, até então, era que mesmo fragmentos de como as escolhas são operadas e quais ações são postas em prática para construir um filme fossem mostrados no interior do próprio filme.

As entrevistas, grosso modo, nos dão exemplos claros da relação assimétrica entre o eu e o outro. A relação de interação, embora provoque mútua influência, pressupõe um observador que, via de regra, controla suas reações a fim de torná-las pouco visíveis. O modelo pergunta-resposta estimula maior exposição do outro: é sua vida ou são suas opiniões, gestos e atitudes os alvos daquele que pergunta e observa atentamente. Por vezes o entrevistador faz-se invisível na tela, sua voz é cortada e mesmo marcas do aparato cinematográfico - como, por exemplo, o microfone - são retiradas do campo de visão da câmera. Constrói-se assim a sensação de que o entrevistado fala diretamente ao público. Este recurso pode contribuir para amenizar a percepção do espectador diante da relação vertical característica da entrevista.

Em Crônica de um verão a relação assimétrica entre o eu e o outro é clarificada. Quando os diretores tornam-se também atores, eles ajudam a expor para o público os mecanismos de construção do filme. A primeira entrevista com a secretária Marylou mostra melhor o papel daquele que observa. Marylou assume um tom confessional e desnuda-se, lançado olhares ora para a câmera, ora para Morin, ora para lugar algum. Assim, ela parece alternar momentos em que fala para si mesma, com outros em que toma consciência da presença dos observadores. Por vezes, chega a manifestar certo desconforto diante dessa relação ou da exposição a que se submeteu. Sua atitude contrasta com a do entrevistador, Morin. Em suas falas, ele colabora com a exposição de Marylou, falando dela para ela mesma (e para o público), enquanto preserva a própria intimidade. Ele e a câmera permanecem observando-a. Ela sabe disso e nos diz com seus olhares. O contraste visível entre as atitudes de um e de outro ajudam a explicitar para o público a relação assimétrica inerente ao processo de comunicação entre o observador e o observado.

E quando um representante qualquer do aparato cinematográfico não está visível na cena, ainda assim podemos vê-lo agir. Morin volta a entrevistar Marylou, agora menos 
depressiva. O entrevistador a incentiva a falar dos acontecimentos que teriam mudado sua atitude diante da vida, mas ela pede para não mais tocar nesse assunto. Ele concorda, seguindo a promessa inicial do filme, aquela feita por Rouch a Marceline, e o assunto é encerrado. Ou assim parece. Marilou, nessa segunda cena, retorce os dedos contra o apoio da cadeira, esconde o rosto entre as mãos e já não quer falar. Mas não se esconde da câmera. E aquilo que não podia ser dito é revelado pela imagem. Vemos um homem a acompanhando e, na rua, eles seguem de mãos dadas. O observador Morin foi convidado a se retirar da cena, fez-se invisível e mudo, mas o lugar do observador não ficou vazio. Com a proibição da entrevista, a câmera ampliou sua participação e as imagens puderam falar por si.

Se a presença visível dos diretores Morin e Rouch nos diz da presença na cena do aparato cinematográfico, a invisibilidade deles não significa a ausência do aparato. Por isso um não se confunde com o outro, nem se resume a ele. No interior do filme eles constituem personagens e têm um papel definido: o de diretores trabalhando na feitura de um filme. Nesse sentido eles representam no interior do filme o papel do observador e, consequentemente, do aparato cinematográfico.

Em Crônica de um verão todas as cenas acontecem para o filme e porque o filme está sendo feito. A câmera ou, mais precisamente, o aparato cinematográfico provoca os acontecimentos. Os atores são motivados a agir e convidados a participar, a falar, a se expor. Decorre disso que o outro não é apenas alguém de quem falamos. Mesmo se seus gestos, ações e falas são motivados pelo aparato cinematográfico, o outro se expõe em suas próprias palavras. O filme surge dos acordos feitos entre o eu-aparato cinematográfico e o outro que a ele se oferece. Assim mais que uma técnica baseada no uso de equipamentos leves e móveis, o experimento do cinema-verdade, anunciado no início do filme, oferece ao público a possibilidade de deslocar os papéis desgastados de observador e observado, expondo os limites da observação e admitindo o outro como sujeito do processo interativo.

\section{O espaço sagrado e o espaço cênico em Os tambores do passado}

Diferente das experiências analisadas anteriormente é a conduzida em Os tambores do passado, pois o rito mostrado no filme deveria acontecer independente da presença da câmera. Rouch e sua câmera foram convidados para assistir e filmar um rito de possessão organizado na região de Zarma, povoado Songhay, para pedir a proteção da colheita aos espíritos. O rito aconteceria na cidade Simiri, no Niger. Na ocasião seriam utilizados os tambores arcaicos Tourou e Bitti. O aparato cinematográfico se fez presente, mais uma vez mostrando a impossibilidade da não interferência. Como teria sido o rito caso a câmera não estivesse lá é 
algo difícil de saber, pois talvez nem mesmo a possessão mostrada no filme tivesse acontecido.

Quando Os tambores do passado começa, uma fala explica ao público que desde o meio-dia se aguardava o início das possessões. O fim da tarde se aproximava e logo não haveria mais luz para filmar. A equipe decide, então, entrar em cena. O cinema etnográfico em primeira pessoa logo oferece uma das primeiras marcas: o uso do pronome "nós" numa clara referência ao aparato cinematográfico. O "nós" refere-se àquele que filma, e empresta sua voz ao filme (o próprio Rouch), e ao operador de som, mas também ao espaço cênico que é próprio ao cinema. Esse "nós" não é uma pessoa genérica, impessoal, própria do discurso científico. As falas de decisão e as escolhas pessoais se colocam no interior do espaço ritual. As imagens, filmadas com câmera subjetiva, também assumem a primeira pessoa, seguindo um ritmo próprio, marcado por uma marcha lenta e pela ausência de cortes. O "nós" anunciado não remete apenas às pessoas, mas também aos equipamentos que entram no espaço do rito e à lógica operacional do cinema.

"Entrar em um filme é mergulhar na realidade e ser, ao mesmo tempo, presente e invisível", diz Rouch caminhando em direção ao espaço do rito. A presença seria marcada por ações e gestos que interfeririam no espaço onde se está e, consequentemente, fazendo-se notar. A invisibilidade seria o oposto disso, ficar-se-ia tão quieto e discreto a ponto de não ser visto. Mas como conciliar em uma mesma situação o agir e o não ser notado? A resposta que o filme oferece é a possibilidade de integração entre os dois espaços, o cênico e o ritual, a princípio separados. No momento em que se diluem os fronteiras que separariam duas lógicas de funcionamento diferentes e se aceita a presença do diferente como um semelhante, os gestos e ações do forasteiro deixam de ser percebidos como um distúrbio e passam a integrar o espaço. É pela proximidade, pela construção de uma relação de pertencimento, pelo aceite das diferenças que a invisibilidade pode ser possível quando em presença do outro.

As imagens mostram que esse eu-aparato cinematográfico não pretende guardar distância daquilo que filma. Aos poucos, ele avança em direção ao lugar do rito, aproxima-se da orquestra de tambores e faz-se notar. Nesse processo de interação entre duas lógicas de funcionamento distintas, o filme e o rito, aquele faz mais do que anuncia. A ideia inicial de realizar um documento filmado sobre os tambores antigos dará lugar à interação entre os dois modos de funcionamento. No centro da roda e ao som dos tambores, os passos do homem que faz a dança da possessão são seguidos de perto pela câmera. Assim como esse homem, o aparato cinematográfico, ao segui-lo, parece também dançar enquanto aguarda a chegada do 
espírito. Os homens dançavam há quatro horas ao som dos tambores antigos sem serem tomados pelo espírito. Quando a câmera insiste em filmar, o espírito chega.

Seguindo esse homem, o aparato cinematográfico se aproxima da orquestra. Em certo momento a orquestra para. E Rouch se questiona: "Nós também deveríamos parar?". Mas decidem continuar, certos de que algo pode acontecer. Os tambores retomam seu ritmo e a possessão acontece. Já corporificado no homem, o espírito não desconhece a presença da equipe de cinema. Ele segura o rosto de um dos músicos e o torce em direção à câmera. $\mathrm{O}$ possuído também lança em direção à equipe do filme alguns breves olhares. Vemos, então, como o aparato cinematográfico não observa à distância, mas entra no espaço do outro e passa a fazer parte dele. Esse espaço deixa de ser apenas o lugar sagrado onde acontece o rito para ser também lugar onde acontece o filme: um lugar marcado pela convivência e pela influência recíproca entre o rito que se oferece para a câmera e o aparato cinematográfico. Convidado a assistir ao rito, pensando em documentar uma prática em vias de extinção (o uso dos tambores arcaicos), o encontro entre o rito e o cinema não se deu sem a transformação de ambos. O que se pensava como um registro tornou-se agente e o espírito que parecia já não responder aos tambores antigos, estimulado pela presença da câmera, comparece ao rito em sua homenagem. Colleyn (2008) trabalha com a hipótese de a câmera ter funcionado como um catalisador "um pouco a maneira dos tambores", acelerando "um transe que estava latente". Ele conta que as pessoas do Simiri que já haviam visto filmes de Rouch acreditavam na possibilidade de a câmera também ver os espíritos, uma vez que ela capturava imagens e as organizava. Assim, se Rouch não parou de filmar quando a orquestra começou a desistir do rito é porque ele via, através da câmera, algo diferente. Stoller nos ensina algo que ultrapassa os limites do filme, mas do qual este pode ser expressão. Um provérbio Songhay diz: "um não iniciado não pode entrar no círculo da dança de possessão" (citado em Stoller, 1992: 161). E se Rouch foi aceito é porque de alguma forma era considerado um iniciado. Rouch convivia com os Songhay e filmava seus ritos desde os anos 1940, de forma que sem deixar de ser estrangeiro, tornou-se semelhante. As falas de Colleyn e Stoller dizem de uma relação que ultrapassa o momento da filmagem. Pela convivência, pela atitude de dividir com os Songhay os frutos de suas pesquisas, os filmes, Rouch se fez aceito. Ao entrar no espaço do rito ele não é mais percebido como o estrangeiro, o observador distante. Através da construção de uma relação de cumplicidade que transcende o momento da filmagem foi possível romper as fronteiras que separariam rito e filme.

Mas o aparato cinematográfico retoma seu projeto inicial quando a filmagem chega perto dos dez minutos. Aos poucos a equipe se retira e o rito deverá continua sem ela. A fala 
em primeira pessoa, a câmera subjetiva, a retomada de um projeto prévio são marcas a dizer para o público como o filme constrói uma visão particular sobre o rito. Uma visão particular de um aparato cinematográfico em particular que, ao ser aceito no centro do espaço sagrado, pôde fazer coincidir o lugar do rito com o lugar do cinema.

\section{Conclusão}

Nesses filmes, a relação eu-outro pressupõe o trabalho de criação dos atores como parte integrante da construção da narrativa e no momento mesmo em que essa se constrói. Ao se oferecerem para o aparato cinematográfico, constituem seu outro e, reinventando-se diante da câmera, servem de base para a construção das personagens e das narrativas. Nos filmes, encontramos dois tipos de personagens: 1) o ator que representa o papel do observado (para ele se direciona o foco do observador e ele age e reage à presença sensível do aparato cinematográfico) e 2) a representação do observador. Em Eu, um negro, a voz de Rouch pontua todo o filme e a figura de um narrador auxiliar se impõe na figura de Robinson. A negociação acontecida nos bastidores permitiu o acesso ao universo de sonhos e desejos dos atores. Em Crônica de um verão, o corpo e a voz dos diretores expõem as estratégias do aparato cinematográfico e as negociações entre o eu e o outro se dão diante da câmera. Já $O s$ tambores do passado constrói uma personagem de voz e olhar, guiando o espectador pelo interior do rito, mas sua atuação ultrapassa a metáfora do olhar. O aparato cinematográfico faz mais que registrar e mostrar, pois é através da câmera que o rito se manifesta, revelando como a relação eu-outro modifica ambos os pólos. Aqui não há um acordo explícito, mas no interior do rito a aceitação do outro o torna invisível como estrangeiro e ele passa a ser mais um no círculo da dança de possessão.

Ao construir personagens capazes de expor, de dentro do filme, os tipos relacionais entre o observador e o observado, os filmes entregam ao público as condições de sua feitura e dos acordos estabelecidos entre o eu e o outro. Os experimentos conduzidos em cada um dos filmes exploram os limites da atuação eu-outro no interior do cinema e propõem a ruptura do antigo modelo, reivindicando a possibilidade de o outro ser também sujeito da narrativa fílmica. Se isso é claro em Eu, um negro e Crônica de um verão, outra é a natureza da ruptura operada em Os tambores do passado. Na busca de agir como observador, o aparato cinematográfico foi convidado a abandonar um lugar próprio, o espaço cênico, e assumir um espaço híbrido em que rito e cinema convivem e se contaminam em suas escolhas e formas de funcionamento. 


\section{Referências Bibliográficas}

BARNOUW, Erik. Documentary: a history of the non-fiction film. New York, Oxford: Oxford University Press, 1993.

COLLEYN, Jean-Paul. Jean Rouch à portée des yeux. Cahiers d'études africaines. França, n. 191, 2008. Disponível em http://etudesafricaines.revues.org/index12552.html. Consultado em 15 de outubro de 2010.

GOFFMAN, Erving. A representação do eu na vida cotidiana. Petrópolis: Vozes, 1996.

HAFNER, Pierre. Les avis de cinq cinéastes d'Afrique noire (Oumarou Ganda). CinémAction. Paris, n. 81, p. 97-99, 1996.

MARSOLAIS, Gilles. L'aventure du cinéma direct revisitée. Québec: Les 400 coups, 1997. (collection cinéma)

NICHOLS, Bill. Representing Reality. Bloomington: Indiana University Press, 1991.

NICHOLS, Bill. Introdução ao documentário. Campinas: Papirus, 2005.

NINEY, François. L'épreuve du réel à l'écran: essai sur le principe de réalité documentaire. Bruxelles: De Boeck Université, 2002.

PASSEK, Jean Loup (Dir.) Dictionnaire du Cinéma. Paris: Larousse, 1991.

STOLLER, Paul. The Cinematic Griot: the ethnography of Jean Rouch. Chicago, Londres: The University of Chicago Press, 1992. 